\title{
Causation and Effectuation: An Exploratory Study of New Zealand Entrepreneurs
}

\author{
Lauren Pfeffer ${ }^{1}$ and Mohammad Saud Khan ${ }^{1 *}$
}

\begin{abstract}
The aim of this paper is to explore the decision-making processes of causation and effectuation within New Zealand entrepreneurs. Oneon-one, semi structured interviews were conducted to investigate; the extent of Causation and Effectuation followed by entrepreneurial start-ups in years four to eight of operation? In Addition, whether decision-making process and perceptions of market uncertainty differ across industries? Findings indicate that effectuation was predominantly followed. This research extrapolates new, key themes regarding decision-making. The decision-making process was largely seen as entirely subjective and dependent on the personality of the entrepreneur, their opportunity recognition experience and ideals of running the business.
\end{abstract}

Keywords: Causation; effectuation; decision-making; strategic decision-making; personality; opportunity recognition; entrepreneur

Submitted: May $5^{\text {th }}, 2017$ / Approved: April 19 $9^{\text {th }}, 2018$

\section{1.- Introduction}

Entrepreneurial start-ups are characterised by uncertainty. They fight to survive and with little tangible and intangible resources it can be difficult for the entrepreneur to know how to best organise the emerging venture. Not surprisingly, much literature surrounds entrepreneurial start-ups to understand their decision-making processes when responding to complexities and uncertainties of challenging environments.

Over time many theories have emerged of how decisions are made, from the normative model based on the notion that decisions follow a multi-step goal driven model/process? between alternatives that follow an orderly path, to James G. Marchs' work on challenging the dogma of pre-existing goals to argue that we make decisions under uncertainty (Augier, 2004). Another notable theory is that of Karl E. Weick, who argues that goal driven-decision making is not how decisions are made, rather we make sense of our environment and rationalise decision-making from there (Starbuck, 2014). Whilst, Mintzberg also challenges the rational model and argues how, in an entrepreneurial setting, decision making is much more difficult and there is often the need to make decisions before we have rational information (Mintzberg \& Westley, 2001).

As decision-making literature shifted from the rational model, to more critical perspectives of Weick and Mintzberg, the focus moved to how entrepreneurial decision-making being made in uncertain environments cannot be rational. This study specifically focuses on the decision-making theories of causation and effectuation which were derived by Sarasvathy in 2001 and accounts for making decisions under uncertainty. Sarasvathy argued that decision making needs to be adaptive over time and responsive to change. She argues that decision making logics shift over time when early venture creation requires flexible, collaborative decision making and later venture creation requires a more planned approach like the normative model (Sarasvathy, 2001).
Causation and effectuation have gained significant interest in strategic entrepreneurship literature as they provide insights on how decisions are actually made in new ventures. Currently the literature argues that effectual logic is followed in the early stages of venture creation as this requires flexibility and working with limited means. As the venture becomes more established, it is argued that decision-making logic shifts to a causal approach. This means more planning and pre-existing goal formation as historic decision-making is typically described (Sarasvathy,2001). While there have been many articles testing when effectuation logic is used (Brettel et al., 2011; Read et al., 2009) the research focuses on the earlier stages of venture creation. Additionally, where research on later stages of venture creation has been conducted, it typically focuses on one industry (e.g Reymen et al., 2015). Consequently, the literature is lacking in the coverage of the later years of venture creation in a cross-industry approach with different levels of uncertainty.

This study aims to explore the following questions in a New Zealand context;

(1) To what extent is Causation and Effectuation followed by entrepreneurial start-ups in years four to eight of operation?

(2) Does the decision making process and perceptions of market uncertainty differ across industries?

The paper makes the following contributions. Firstly, it sets out to distinguish whether causation and effectuation is more predominant within New Zealand start-ups and whether causation is predominantly followed, as suggested, in years four to eight. Secondly, this work advances our theoretical understanding on how uncertainty drives the usage of a certain decision-making process (causation and effectuation). And finally, this work demonstrates whether key strategic decisions can shift the decision-making process being used. Summing up, the work investigates the theoretical understanding of 'how' these decision-making processes come into place in each venture and 'why' they are being followed.

(1) School of Management, Victoria Business School, Victoria University of Wellington, Wellington, New Zealand. ${ }^{\star}$ Corresponding author: saud.khan@vuw.ac.nz 


\section{2.- Theoretical background}

Prior to Sarasvathy (2001), the normative model dominated based on the notion that decisions follow a multi-step goal driven process to choose between alternatives that follow an orderly path from problem identification through to solution (Franklin, 2013). Opportunities are discovered through a purposeful search process. This is the model employed by neoclassical economics where the decision making process involves defining, diagnosing, designing and then finally making the decision (Mintzberg \& Westley, 2001).

Today, this rational normative model is referred to as causation, however, many behavioural theorists had previously challenged the normative model, the notable being: James G. March, Karl. E. Weick and Henry Mintzberg (Sarasvathy, 2001).

James. G. March challenged the notion of rational goal driven decisions arguing, we cannot make decisions in terms of a goal that will only be known later. He challenges the dogma of pre-existing goals and called for better models of decision-making (Augier, 2004). March subsequently derived the theory of Garbage-Can decisionmaking, which focused on the meaning of choice and how it changes over time due to the introduction of new problems and changing patterns of available energy. Choice opportunity can be seen as a garbage can into which participants dump various kinds of problems and solutions as they are generated and consequently rational decisionmaking does not happen in reality (Cohen et al., 1972).

Karl E. Weick also argued that rational, goal driven decision-making was not how decisions are made. He said, rather, we all engage in "sense making"; which involves the ongoing retrospective development of plausible images that rationalize what people are doing" (Obstfeld, Sutcliffe \& Weik, 2005, p.409). We engage in this process when the current state of the world is perceived to be different to what is expected. Instead of making, rational decisions, we search for meaning and how we make sense of the environment determines our decisions (Starbuck, 2014). He proposed that change occurred through the theory of enactment, selection and retention which is similar to natural selection results in arranging enacted experiences that allow retention of the products of successful sense-making (Weick, 1982).

Notably, Mintzberg work also challenges the rational model. Famous for his work on strategy as an emergent unplanned process, he argues that decision-making is messy and is not rational because new events interrupt the process. Mintzberg argues that 'thinking first', 'seeing into' and 'doing first' should be used in combination because understanding requires the courage to see what others cannot and to recognize things for what they are. (Mintzberg \& Westley, 2001).

\section{Causation and Effectuation}

Sarasvathy (2001) sought to expand on March's questions arguing that the landscape of business was changing towards a more free-market orientated and entrepreneurial setting where decision-making becomes much more difficult and we sometimes have to make decisions before we have the rational information - "how do we make a price decision when the firm does not yet exist and there is no demand function, how do we value a firm in an industry that didn't exist five years ago" (Sarasvathy, 2001, p.244). This led to her redefining the rational approach and the emergence of effectuation. "Causation processes take a particular effect as given and focus on selecting between means to create that effect." "Effectuation processes take a set of means as given and focus on selecting between possible effects that can be created with that set of means" (Sarasvsthy, 2001, p. 45).

Sarasvathy outlined seven areas that show the differences between causation and effectuation. These are givens, decision-making selection criteria, competencies employed, context of relevance, nature of unknowns, underlying logic, and outcomes. Effectuation was a paradigmatic shift to the way we understand the entrepreneur and suggests how individuals might act in situations in which the assumptions of causal approach are not met (Edelman \& Yli-Renko, 2010).

An entrepreneur with an effectual decision-making process focuses on what they can control, rather than achieving pre-existing goals. The effectual entrepreneur uses the resources they have at their disposal, and embraces uncertainty, rather than avoid it like a causal model where any change to the plan is unwelcome (Sarasvathy, 2008). In the effectuation processes there is still a predetermined goal, but it is flexible in nature allowing the entrepreneur to create one or more possible effects irrespective of their original goal and to therefore change and shape their goals over time. There is a focus on strategic alliances rather than competitive analysis of causal models that require extensive time and financial resources.

Since Sarasvathy (2001), many have sought to validate and measure the effectuation model and empirically test it (Brettel et al., 2011; Read et al., 2009). Chandler et al., (2009) validations study proved the effectuation model. There has been a consensus throughout literature that effectuation is followed at the early stages of venture creation, and causation followed once the business becomes established. The work of Reymen, et al., (2015) explored Sarasvathy's comment that causation and effectuation processes happen interchangeably, and explored when effectuation is predominately followed over causation, and vice versa. This research confirmed that causation and effectuation happen interchangeably and added that initial conditions (level of uncertainty, novelty of the market) determine the process followed, however there is always one predominant process used.

Reymen et al., (2015) found when the entrepreneur engages in strategic decisions to change the scope of their activities, such as product offerings, technologies or markets, this shifted the used of decisionmaking logic. The overall pattern is when the scope of the venture is widened, then market uncertainty is high and the effectuation process comes into play. Narrowing the scope of activities, therefore, leads to a particular focus that requires goal formation, perceived market uncertainty becomes low leading to usage of causation processes.

\section{Entrepreneurial Strategic Decision}

According to Shoemaker (1993) Strategic decisions are "intentional choices or programmed responses about the issues that materially 
affect the survival prospects, well-being and nature of the organization" (Mehrabi \& Mohammad, 2012, p.179). The four characteristics of strategic decisions are complexity, uncertainty, rationality, and control. There are numerous factors that affect strategic decision-making including, the environment, the entrepreneur's characteristics, and the decision-making process itself (Mehrabi \& Mohammad, 2012).

Strategic decision-making is essential to entrepreneurial strategic management and is a viable pathway to wealth creation through increased financial returns. Therefore, engaging in the right strategic decisions and decision-making processes for the venture derives adequate strategic management and the ability to prosper and most importantly, survive (Kearins, Luke \& Verreynne, 2010). However, one challenge of strategic decision making is that when managers make strategic decisions they change their perceptions of the environment to make it 'appear' more certain as a business cannot address its environments impact (Schwenck, 1984).

Personality is another dimension developed by McCarthy (2003), arguing that entrepreneurs are either charismatic or pragmatic individuals. The pragmatic entrepreneur leads to rational, goal setting or 'causal' decision-making. In McCarthy's illustrations, she found that a planned approach is used and decisions were made "very carefully" in order to reduce the risk of business failure (McCarthy, 2003, p.332). Charismatic entrepreneurs, on the other hand, had ambitious goals and welcomed risk - an effectual decision-making process. Other themes throughout literature are opportunity recognition and perception (Alvarez \& Barney, 2007). Prior research says causation and effectuation are not entirely affected by the length of time the venture has been in existence. Entrepreneurial experience was proved to have no effect on the type of decision-making process entrepreneurs followed (Reymen et al., 2009). These factors are important as they do play a role in the decision-making process followed by an entrepreneur.

Effectuation clearly has a place in literature as the main decisionmaking tool of entrepreneurs operating in uncertain environments. However, the notion that both processes are used together, has led to some research examining when each process is used. Extant literature posits varying findings depending on the length of the process, market uncertainty, strategic decision-making and the type of entrepreneurial personality have been reached. Therefore, this research intends to focus on entrepreneurs at a later stage (years 4-8) of venture creation, across a range of industries to viz-a-viz causation and effectuation.

\section{3.- The 'study'}

This section details the research perspective; what paradigm was adopted and how this determines the research design, the methodology, data collection and analysis.

\section{Research Perspective}

This research project is qualitative and therefore typically follows an interpretivist paradigm. The ontological essence of this paradigm assumes that reality is constructed through the meanings and understandings developed socially and experimentally (O'Leary, 2014). Holding this epistemological position means as the researcher we do not separate ourselves from the research. It calls for inductive logic; appreciates subjectivities and accepts multiple perspectives and realities. Inductive reasoning involves making observations from raw data, discerning a pattern, making a generalization and then inferring an explanation or theory (O'Leary, 2014, p. 130). The value of qualitative over quantitative is that qualitative research delves into social complexities in order to truly explore and understand the interactions, processes, lived experiences, and belief systems that are part of individuals' institutions, cultural groups, and even the everyday (O'Leary, 2014).

\section{Methodology}

This paper takes a phenomenological methodological approach. This is "the study of phenomena as they present themselves in individuals' direct awareness and experience. Perception, rather than socio-historic context or even the supposed 'reality' of an object, is the focus of investigation" (O'Leary, 2014, P. 138). This epistemological position and methodology was chosen because the project required an in-depth understanding of entrepreneurs decision-making, which is challenging to achieve through quantitative surveys. Rather, in-depth discussions with each participant are needed to ask them a series of questions regarding the key elements of their business, goal setting and environment. In short, the aim was to deceiver 'how' they make decisions and why, quantitative methods could not obtain this complex information.

\section{Research Design}

\section{Sample Description:}

The research considers entrepreneurial start-ups that are operating in the later years of their business with a focus on their decision-making processes. The key question being whether entrepreneurs follow Causation and/or Effectuation processes after years 4-8 of operation and what process is the more dominant. The population was limited to entrepreneurs who continue to run their business and are heavily involved in day-to-day operations after 4 to 8 years since start-up. Five entrepreneurs, one each from the following five industries constituted the study sample; Skincare, Technology, Equine hoof care, Business Management and Food. These industries represent a diverse sample, offering varying dynamics.

Furthermore, as entrepreneurial literature focuses on the high tech industry it is relevant to explore a cross-industry approach to understand how relevant decision-making processes work in different contexts. Literature already shows how effectuation is more prominent in the early stages of a venture while causation can become more prominent later. However, the literature states that these shifts in decision-making logic can be greatly altered by the sector/industry environment and the entrepreneur's perception of its uncertainty as uncertainty is a key factor in decision-making. 
Table 1: The realised sample

\begin{tabular}{|c|c|c|c|c|c|}
\hline Participant & Pseudonym & Industry & What they do? & Motive For Entry & $\begin{array}{l}\text { Years in } \\
\text { Operation }\end{array}$ \\
\hline 1 & A & Skincare & $\begin{array}{l}\text { Sells and formulates NZ made } \\
\text { skincare }\end{array}$ & $\begin{array}{l}\text { The entrepreneurs past job } \\
\text { experiences as well as caring } \\
\text { about what products she put on } \\
\text { her skin }\end{array}$ & 5 \\
\hline 2 & B & $\begin{array}{l}\text { Professional Services } \\
\text { and Technology }\end{array}$ & $\begin{array}{l}\text { A digital performance company that } \\
\text { focuses on digital marketing }\end{array}$ & $\begin{array}{l}\text { The founders attended a inter- } \\
\text { net marketing conference and } \\
\text { saw a compelling opportunity }\end{array}$ & 7 \\
\hline 3 & $\mathrm{C}$ & Equine Hoof care & $\begin{array}{l}\text { Team of farriers that provide hoof } \\
\text { care services to a wide range of } \\
\text { equine breeds and disciplines. }\end{array}$ & $\begin{array}{l}\text { The entrepreneurs qualification } \\
\text { as a farrier combined with his } \\
\text { passion for horses }\end{array}$ & 8 \\
\hline 4 & $\mathrm{D}$ & $\begin{array}{l}\text { Business Manage- } \\
\text { ment }\end{array}$ & $\begin{array}{l}\text { Develops a online collaborative } \\
\text { decision-making tool }\end{array}$ & $\begin{array}{l}\text { The desire to solve the problem } \\
\text { of inclusive equitable deci- } \\
\text { sion-making }\end{array}$ & 5 \\
\hline 5 & $\mathrm{E}$ & Food & $\begin{array}{l}\text { Makes cakes, cupcakes and other } \\
\text { sweet treats in store and for order }\end{array}$ & $\begin{array}{l}\text { The entrepreneurs passion for } \\
\text { baking }\end{array}$ & 4 \\
\hline
\end{tabular}

\section{Method}

A qualitative study is well aligned with semi-structured interviews to collect data. Interviews are "a method of data collection that involves researchers seeking open-ended answers related to a number of questions, topic areas, or themes" (O'Leary, 2014, p.217).

The reasons interviews were suitable for this research project, is because they provide rich, in-depth qualitative data, allowing for nonverbal as well as verbal data so this means really 'seeing' how the respondent feels about something, giving the researcher a more in-depth understanding. Interviews are flexible enough to allow you to explore tangents, yet are structured enough to generate standardised, generalised data (O’Leary,2014).

For this project, a semi- structured interview was considered suitable to produce optimal insights. A semi-structured interview is an interview with the use of a flexible structure, which can start with a defined question plan but deviate in order to follow the natural flow of conversation and pursue interesting tangents (O'Leary, 2014, p.218). One - to -one interviews were seen as most suitable. These were seen necessary to give control over the process and the freedom to the interviewee to express his or her thoughts freely.
Prior to the interviews an interview schedule was devised based on the literature review and understanding of what was needed to answer the research questions. This included prompt questions as well. The questions included themes of goal setting, entrepreneurs perception of their environment, uncertainty and risk, as well as talking through a strategic decision that they made.

\section{Data Analysis}

Template analysis was used to thematically analyse qualitative data. The analysis involved developing a coding template, which summarised themes identified as important in the data set, and then organised them in a meaningful and useful manner. This involved hierarchical coding - which meant using broad themes that encapsulate more specific ones.

Once the themes were identified the data was read through and relevant segments were marked and checked with a priori themes to eventually code on the transcript. All transcripts were analysed and this template served as a basis for interpreting the data set.

\section{4.- Findings}

In this section, the findings are discussed key themes extrapolated from each case. 
Table 2: FINDINGS

\begin{tabular}{|c|c|c|c|c|c|}
\hline Pseudonym & A & B & $\mathrm{C}$ & $\mathbf{D}$ & E \\
\hline Industry & Skin Care & $\begin{array}{l}\text { Professional Servi- } \\
\text { ces and Technology }\end{array}$ & Equine Hoof Care & $\begin{array}{l}\text { Business Manage- } \\
\text { ment }\end{array}$ & Food \\
\hline Years of Operation & 5 years & 7 years & 8 years & 5 years & 4 years \\
\hline Industry dynamics & Competitive & $\begin{array}{l}\text { Very dynamic \& } \\
\text { competitive }\end{array}$ & $\begin{array}{l}\text { Competitive, high } \\
\text { demand }\end{array}$ & $\begin{array}{l}\text { Little competition, } \\
\text { niche market }\end{array}$ & Little competition \\
\hline Personality of Entrepreneur & Charismatic & Pragmatic & Charismatic & Pragmatic & Charismatic \\
\hline Level of Goal Setting & Low & High & Low & High & Low \\
\hline Open to Change? & Yes & Yes & Yes & Moderately & Yes \\
\hline Frequency of Goal Setting & Low & High & Low & High & Low \\
\hline Competitive or Cooperative? & Competitive & Both & Cooperative & Cooperative & Cooperative \\
\hline Personality Driven? & Yes & Yes & Yes & Yes & Yes \\
\hline
\end{tabular}

The findings show that three out of five businesses use effectual decision-making logic in their business. Interestingly, I have extrapolated different findings than what was expected. The following section breaks down the key findings under the key themes of goal setting and flexibility, environment and strategic decision-making.

\section{Business A}

- Goal Setting and Flexibility:

Business A follows an effectual decision-making process. This entrepreneur has an overarching goal for her business though the way she goes about it is subject to change;

"the way we are going to go about doing it kind of unfolds down the track".

She says she welcomes change and understands the importance of learning. Entrepreneur A understands that things disrupt the plan and therefore she must be agile, she voices;

"like yesterday we found out that the new product we just launched, $10 \%$ of the caps are broken". "it's totally ok to change your course".

She holds a general belief that too much planning is not a good thing and strongly believes in using her gut to make decisions.

"you can do all the analysis and preparation in the world but sometimes that will be quite, I want to say halting, it like halts your progress and if you don't take that first step then you're never going to get anywhere, so there's a balance of looking at everything with a magnifying glass and getting out and doing it and going with your gut feel".

To this entrepreneur it is important to have an underlying goal, though she believes in following her gut and let the process of achieving this goal and the formulation of new goals to be organic. 


\section{Environment}

Entrepreneur A views her business environment as competitive. This entrepreneur believes in conducting a competitive analysis to find ways she can compete. However, her industry is characterised by recent changes from external influencers like Facebook and Instagram. Changes to Facebooks algorithm means entrepreneur A perceives her industry as risky at the moment, with an air of uncertainty.

\section{- Strategic Decision-Making:}

Entrepreneur A made a recent strategic decision to produce a new product. Explaining how she came about this decision came from her personal interests as well as communicating with her customers about their wants and needs. She factored quite a lot into this strategic decision, such as her personal strengths, what she needs help with, how she will market the product, how to formulate the product etc. Each decision was made primarily with her gut feel and she let this new product development unfold organically and dealt with decisions as they arose.

\section{Business ' $B$ '}

\section{-Goal Setting and Flexibility:}

The above table shows Business B predominately follows a causal decision-making logic. There is extensive goal setting and structure at Business B that is guided by their formalised vision and values. These goals are formulated in all functional departments with set KPI's and accountability structures set. Goals are set yearly and must be agreed on between the founder's, their desires, the board and shareholders. However, Entrepreneur ' $\mathrm{B}$ ' explains that even though goal setting is extensive and they follow a planned process in order to achieve each goal, they must still remain agile and flexible.

"it's a balance in a small growing business and in our industry when a new technology comes out and you have to be over it. You need a model that can always be a bit agile and adapt, but at the same time you need process and structure around it".

Entrepreneur ' $\mathrm{B}$ ' voices that the growth of the business means they now need to be stringent on taking the opportunities. Therefore, although they are flexible and recognize the opportunities around them, they need structure and a plan:

"if there is more structure, we can't manoeuvre as much".

"now we need to be strategic and have something to pin everything to."

\section{- The Environment:}

According to Entrepreneur B the industry that their business operates in is very dynamic. This is because they need to operate as a professional services company but in the tech space. The entrepreneur voices that this is hard to balance:

"one is a rigid model and the other a lot of disruption. So two things colliding that don't make sense".
The biggest issue for business B is that they are at the mercy of big tech players like Google.

"they could change the rules overnight so you need a model that can adapt with that".

Entrepreneur B voices issues on the effect that new technologies have on the business. These have a huge impact on how people interact with websites and digital advertising that in turn affects the business. Interestingly, Entrepreneur B does not see much concern in these risks, and does not see much uncertainty in the business' industry. Entrepreneur B believes in having the right business model, to be one step ahead and this then reduces the risk. He voices;

"so when it happens you can quickly adapt and move and hire people who love that space. So you build a culture move and adapt."

Though, operating in an industry characterised by disruption and competition, Entrepreneur B is happy to form partnerships and alliances with others. While working with others has enabled fast growth and success Business B still engages in a competitive analysis and strives to outwit competitors.

\section{S.trategic Decision-Making:}

Business $B$ engages in a lot of strategic decision making. However, regardless of the type of decision their decision-making logic does not change. A strategic meeting is held each week that takes all big decisions to a monthly management meeting that looks at financials, marketing etc. Following that a business proposal is completed and then clear performance KPI's around the decisions are formulated. Entrepreneur B says that there is the same planned structure and accountability for all decisions. There is little gut feel and no emergent nature for decision making as business $\mathrm{B}$ has a corporate structure of boards and shareholders.

\section{Business 'C}

\section{Goal Setting and Flexibility:}

At business $\mathrm{C}$ goal setting is done differently compared to other participants in this research. Entrepreneur $\mathrm{C}$ has a set of personal career goals. Such goals are entrepreneur C's desire to make a change in the equine industry and educate those in the industry on good hoof care. Entrepreneur $\mathrm{C}$ wants to develop strong apprentices who will practice sound practices in their careers, too. These goals are visionary in the Equine Hoof Care industry.

However, general goal setting at business $\mathrm{C}$ is not extensive, nor is there any plan or structure in place regarding 'how' these goals will be achieved.

"I have one goal and then I have the next goal in my head".

Entrepreneur C lets the achievement of goals and the formation of new goals organically unfold. Entrepreneur C welcomes change, 
though change isn't something he loves. Rather, he believes change is inevitable and therefore it must be accepted. To entrepreneur C, when a negative event happens disrupting the achievement of a goal, he try's something new to achieve that given goal and he is even more determined to achieve it.

\section{Environment:}

The Equine Hoof Care industry is highly competitive, entrepreneur C voices: "its not easy to be in".

Although this industry is characterised by many competitors who do not work together often, entrepreneur $\mathrm{C}$ is happy to work with others, expressing:

"id work with anyone. I'm not too proud to. If I think they are going to be good for us".

Entrepreneur $\mathrm{C}$ does not perceive this industry as risky or uncertain. $\mathrm{He}$ says there is always demand for farriers, and the business grows money:

"If a horse is shod it will have to be done again 6 weeks later".

To entrepreneur $\mathrm{C}$ there is nothing that can fundamentally disrupt the Equine Hoof Care industry.

- Strategic Decision-Making:

Entrepreneur C made a strategic decision that stemmed from his vision. Though, explaining how this decision came about, entrepreneur $\mathrm{C}$ described how he initially had other plans to achieve his vision of educating those in the industry. The way he went about this decision unfolded as events occurred around him. He made this decision by taking a opportunity he recognised. This decision was not planned out, the enactment of it naturally unfolded with time.

\section{Business ' $D$ '}

\section{- Goal Setting and Flexibility:}

Business D engages in extensive goal setting that is guided by their long term mission. Goals are set annually and then quarterly, these must be approved of by the board. Entrepreneur D communicates that their business is open to change and agile, though does not believe in changing too quickly or too much:

"If you try something new and change too quickly because you fear it might not work you didn't implement it enough to see success or failure."

"Change is high cost and hard to get everyone on board, and slow."

\section{- Environment:}

Entrepreneur D describes their business' environment as dynamic. They serve a niche market. There is not much competition, only competitors that do 'similar' things. Though Entrepreneur 'D' does not believe in competing:
"I welcome other players in this space cause the more we can do that the better the society we're going to have".

However, entrepreneur 'D' elaborates;

"I think the only reason I'm not worried about it because I don't think any people would make this tool because the design of it comes from a deep connection from certain kind of processes from collaborative groups which we are. That a very profit focused or mainstream company would never think of this or see the value of this. I don't think they would and that's why they haven't."

\section{Strategic Decision-making:}

Business 'D' engages in strategic decision-making often. However, regardless of the type of decision conducted, the process remains the same. Decisions are guided from the top level goals of the year and the people in each group are held accountable for decisions in their area. Key strategic decisions that affect the survival prospects such as capitalising the business, go straight to the board for approval. Therefore, big decisions remain structured at business ' $D$ '. however, entrepreneur ' $D$ ' communicates that though big strategic decisions require boards approval and are accountable to certain members of the business, the process of making a decision shifts depending on the decision made.

"We try be really conscious of different levels of decision making and when someone should be empowered to just do something".

Entrepreneur D believes that people should sometimes use their judgement in decision-making. She also voices that when strategic decisions are being made, business D gathers experimental evidence to see how that decision will pan out;

"we gather experimental evidence. We do the lean start up approachthe smallest thing we can do to test this".

Therefore, even though business D's strategic decision-making is guided by the formalised goals, strategic meetings and must be approved by the board at times, entrepreneur D still believes in experimenting and learning whilst engaging in strategic decision-making.

\section{Business ' $\mathrm{E}$ '}

$$
\text { - Goal setting and Flexibility: }
$$

Entrepreneur E is very attached to her business and produces goals that are two fold. Goals stem from her personal wants and also what is best for her business. However, she does not communicate any underlying goals, rather formulates goals as she goes along, voicing;

" when we started the goal was to survive, after a while the goal changed and we realised we were doing quite well, the goal changed $a$ bit and it became to open the retail shop and then, when we had the retail shop the goal became to open another one."

Now that business ' $E$ ' has substantially grown in size, goals are still flexible. Entrepreneur E is very happy to change her goal if she sees a 
good opportunity - change does not worry her, she would rather take the opportunity than miss out on something great. Though, because entrepreneur $\mathrm{E}$ has a strong personal attachment to her business, if something were to come and disrupt a goal she would take it quite personally.

\section{- Environment:}

Entrepreneur E perceives her market as low risk with little uncertainty. This is because to entrepreneur E competition is not extensive with only three to four direct competitors. She does not worry about the competition because in her view each competitor has their own strengths. Entrepreneur E is happy to work with others and it is evident she does not have a competitive personality:

"If someone comes and asks for something other people will do better than me, I'll send them to the other cake people"

However, entrepreneur E admits that there has been a few more competitors popping up. Though she is not worried because she believes business $\mathrm{E}$ has its own unique product offering that will offset any increases in competition or current trends. Entrepreneur E also expresses social issues that could be seen as a threat - one example is the sugar debate that she admits could put people off baking. Though, once again she is not too worried and views her market as stable.

\section{- Strategic Decision-Making:}

Business E engaged in a strategic decision that was to open a new store. Entrepreneur E says this goal was one of her step goals, though she had no plan in how she would go about this decision. Entrepreneur E shows no sign of a causal approach to this decision, rather it happened organically and she made decisions as they occurred.

She did not perceive this decision as uncertain, rather entrepreneur E said she felt comfortable widening her scope as she is a local of Wellington and knows where the competition is and what kind of customer she would expect at her new shop.

\section{5.- Discussion}

Understanding how entrepreneurs make goals, and achieve them was the first major theme of this research.

\section{Effectuation processes.}

While Business A has an overarching goal, how she achieves it and the sub-goals she develops in between are not set. There is no plan - it unfolds down the track. This entrepreneur does not believe in too much analysis and preparation and (she) would rather follow her gut feel and take the opportunities she sees. Business B was much the same with goal setting being personal and visionary. They were career goals in different and unique areas that have no set plan to get there. Additionally, Business E's goals were two fold, both personal and business goals. They formulate in time and are flexible.
All entrepreneurs welcomed change and saw it as an opportunity, citing that you need to be flexible in business and change does happen. We can infer these three businesses follow an effectual decisionmaking process. The sample does not fully match Sarasvathy's (2008) claim that businesses following an effectual process are more likely to engage in strategic alliances rather than competitive analysis that require extensive time and resources.

Business A, an effectual entrepreneur, adamantly engages in competitive analysis. She is most probably the participant who engages in these processes more interchangeably than the other participants who are viewed as purely effectual. To her this is necessary, she needs to compete with others- there's no one rationale for this, rather than the reoccurring theme of personality- it is in her personality to do so.

On the other hand, businesses $\mathrm{C}$ and $\mathrm{E}$ both engage in strategic alliances, once again, not because they don't have the time and resources to undertake a competitive analysis, but because it is their personality to work with others. Business $\mathrm{C}$ sees it as a way to learn and welcomes it typically in an industry where most players would not engage in this kind of alliance as it is characterised by competition. Business $\mathrm{E}$ is not a competitive person. She would rather recommend competitors to customers whom she thinks can do a better job than her on a specific product, highlighting the personality aspect, again. Though they are still relatively young, these businesses are established, and none is in the position of merely trying to survive anymore. Therefore, Sarasvathy's (2001) resource debate of a competitive analysis does not hold true to this sample.

On the other hand, Business B and D were quite different. These two businesses had a lot of formalised structure in place regarding goal setting. These businesses set out to achieve the pre-existing goals which have been formulated through many meetings with boards, owners and shareholders. These goals are put in annual plans and are organised to achieve with key KPI's, accountability structures and so forth. This is evidently a causal decision-making model. Interestingly, Sarasvathy (2001) says that businesses following a causal process do not welcome change in their plan and are likely to engage in a competitive analysis. However, the reoccurring theme of personality shows this not to be true. Business B strongly believes in being agile, stating that they need to be as a growing business and the industry they are in. However, to them this doesn't stop goal setting and performance targets being formulated, it just makes them alter their model and produce change if they need to. While they take a predominately competitive stance in the market, business B had many strategic partnerships in place too.

Whilst, Business D was more set on each goal, voicing the drawbacks of change and how things needed to be tried long before there should be any change. Also, business D believes purely in a collaborative approach and no competition. This stems from the business being collaborative in nature and the personality of those that run it. Therefore, Sarasvathy's (2001) claim does not hold true here that when causal processes are dominant, flexibility and alliances are not followed. It ultimately comes down to the business and the people running it. 
Shoemaker (1993) said that strategic decisions are "intentional choices or programed responses about issues that affect the survival prospects, wellbeing and nature of the organisation" (Mehrabi \& Mohammad, 2012, p.179). Reymen et al., (2015) said that when the scope of the venture is widened then market uncertainty is increased and the effectuation process is used and narrowing the scope of activities leads to particular goal formation, with perceived market uncertainty low and therefore a causation approach is used. However, this study found that regardless of the scope of the strategic decision, the decision-making process did not change. For example, while business $\mathrm{A}, \mathrm{C}$, and $\mathrm{E}$ all made decisions with effectual logic, they did not use effectual logic because of increased market uncertainty, but because of their personality and how they always run their business. Business B is another example of entrenched personality driven behaviour - a causal decision-making process is always used even when a strategic decision with increased market uncertainty may call for effectual logic. Causal logic has always been used because that is how they run their business and deal with uncertainty, they plan, set goals to deal with this.

This study emerges the theme that the environment does not determine what decision making process is followed; the entrepreneur, their subjective opinions, the business itself is what determines it. This reaffirms Reymen et al., (2015) who researched IT firms at the later stages of venture creation finding they followed causal decisionmaking. One IT firm in this study affirmed this as they followed Causal approach too - however from this one interview in each industry it is not possible to say if the industry makes Business B use causal decision-making, it is how the business has always been structured and who runs it. The founders, who operated purely effectually in the very early days, structure their business model around consultants who mentor them and well known business books. They decided to follow this route. Importantly, they believed as they got bigger they needed to have more structure in place.

Another interesting finding was that business A perceived her industry as risky and uncertain because of external influencers like Facebook and on the other hand Business B saw the effect that players like Google can have on their business creating a small amount of uncertainty and risk. Finally, Business $\mathrm{C}$ in an industry characterised by competition and excessive supply, found no risk or uncertainty surrounding this. The resulting theme seems to be that in businesses operating in risky or uncertain markets, it can come down to the subjective opinion and personality of the entrepreneur that determines how they view the environment and their response to it. This study finds no correlation between the perception of uncertainty and what decision-making process is followed.

It was suspected if any of the firms were to continue an effectuation process it would be the younger participants. But this was not the case, one 8 and one 5-year old firm were effectual process users and this signifies that time horizon of operation is not necessarily a factor in this research as to what decision-making process is followed. In the end it is suitable to say that personality, subjective opinions and perceptions appear to ultimately guide the decision-making process used in this context.

\section{6.- Conclusion}

This qualitative study sought to answer to what extent is Causation and Effectuation followed by Entrepreneurial start-ups in years 4-8 of business? It took a cross industry approach asking does the decisionmaking process differ across industries and perceptions of market uncertainty.

Three of the five participants in this study follow effectuation decision-making process and two participants follow the causation process. Interestingly, two out of three of the effectual entrepreneurs showed little signs of causal decision-making, whilst the other shows some use of interchangeably using these two processes. On the other hand, the two causation entrepreneurs show elements of using effectual processes. This study affirms that these processes are used interchangeably by some entrepreneurs. With just one business in each of five different industries and a mix of causation and effectuation approaches it is not possible to say whether industry per se affects the model employed. Instead it was clear that subjective opinion of their market guided their decision making and the most important impact on the process used was the personal characteristics of the entrepreneur, their personality, opportunity recognition and ideals of running a business. The research supports personality based themes of entrepreneurial decision making, rather than scoping decisions and perception of market.

\section{limitations and implications of the study}

The major theoretical contribution of this research is that this study has found that not all firms in the later stages of venture creation follow a causal decision-making logic. Instead, this research has surfaced other themes regarding decision-making; which are personality, opportunity recognition and the ideals of running a business. Practically, this research provides an understanding of how, in reality, entrepreneurs are not making decisions directly in line with the amount of years their business has been operating, and in fact, decision-making is a much more complex and subjective matter.

This research presents few limitations. Self-reported data has the possibility of biases, however, this was controlled by having semistructured interviews that were designed to make the interviewees talk on how they felt and what they thought on various routines. Secondly, the small sample meant we were unable to generate significant insights regarding the correlation aspects of industry dynamics and perceptions of uncertainty. Conversely, initial understandings spark interesting conversations for specific and large-scale research on entrepreneurial decision making within New Zealand.

\section{7.- References:}

Augier, M. (2004). Marching towards "a behavioural theory of the firm": James G. march and the early evolution of behavioural organization theory. Management Decision, 42(10), 1257-1268. doi: $10.1108 / 00251740410568953$ 
Chandler, G., DeTienne, D., Mckelvie, A., \& Mumford, T.(2009), Causation and effectuation processes: A validation study. Journal of business venturing, 26: 375-390. doi:10.1016/j.jbusvent.2009.10.006

Cohen, M., March, J., \& Olsen, J. (1972). A Garbage Can Model of Organizational Choice. Administrative Science Quarterly, 17(1), 1-25. doi: $10.2307 / 2392088$

Franklin, C.L. (2013). Developing expertise in management decisionmaking. Strategic Management Journal, 12(1), 21-37. Retrieved from: http://search.proquest.com.helicon.vuw.ac.nz/docview/1369310720? accountid $=14782$

Luke, B., Kearins, K., \& Martie-Louise Verreynne. (2011). Developing a conceptual framework of strategic entrepreneurship. International Journal of Entrepreneurial Behaviour \& Research, 17(3), 314-337. doi: $10.1108 / 13552551111130736$

Mehrabi,R., \& Kolabi, A.M. (2012). Investigating effect of entrepreneur's personal attributes and cognitive heuristics on the quality of entrepreneurial strategic decision making. Global Business and Management Research: An International Journal, 4 (2), 178+. Retrieved from: http://go.galegroup.com/helicon.vuw.ac.nz/ps/i.do?

Mintzberg, H., \& Westley, F. (2001). Decision-making: It's not what you think. MIT Sloan Management Review, 42(3), 89-93.doi: http:// search.proquest.com.helicon.vuw.ac.nz/docview/224963087?accoun tid $=14782$

O'Leary, Z (2014). The essential guide to your research project ( $2^{\text {nd }}$ edition).London: Sage
Read, S., Smit, W., Song, M. (2009). A meta- analytic review of effectuation and venture performance. Journal of Business Venturing, 24, 583-587. Doi: 10.1016/j.jbusvent.2008.02.005

Reymen, I. M. M. J., Andries, P., Berends, H., Mauer, R., Stephan, U., and Van Burg, E. (2015) Understanding Dynamics of Strategic Decision Making in Venture Creation: A Process Study of Effectuation and Causation. Strategic Entrepreneurship Journal, 9: 351-379. doi: 10.1002/sej.1201.

Sarasvathy, S. (2001). Causation and Effectuation: Toward a Theoretical Shift from Economic Inevitability to Entrepreneurial Contingency. The Academy of Management Review, 26(2), 243-263. Retrieved from http://www.jstor.org.helicon.vuw.ac.nz/stable/259121

Sarasvathy, S. (2008). What makes entrepreneurs entrepreneurial? Retrieved from: http://www.effectuation.org/sites/default/files/research_ paper/what-makes-entrepreneurs-entrepreneurial-saravasthy-0.pdf.

Schwenk, C. R. (1984), Cognitive simplification processes in strategic decision-making. Strategic Management Journal, 5, 111-128. doi:10.1002/smj.4250050203

Starbuck, W. H. (2015). Karl E. weick and the dawning awareness of organized cognition. Management Decision, 53(6), 1287-1299.doi: 10.1108/MD-04-2014-0183

University of Huddersfield. (n.d). What is Template Analysis?. Retrieved October 1, 2016, from http://www.hud.ac.uk/hhs/research/ template-analysis/what-is-template-analysis/

Weick, K.E. (1982). Review of Introduction to Organisational Behavior. Contemporary Psychology: A Journal of Reviews, 27 (2), 154 
